\title{
Contribution and Priority Action of the Self-Efficacy and Organizational Climate to Improve Innovative Work Behavior
}

\author{
Yuyun Elizabeth Patras \\ Universitas Pakuan \\ yuyunpatras64@gmail.com \\ Rais Hidayat \\ Universitas Pakuan \\ rais72rais@gmail.com \\ M. Arif Billah \\ Pusdiklat PLN \\ muh.arief.billah@gmail.com
}

\begin{abstract}
Innovative work behavior is very important to continue to improve through improving the variables that affect it such as organizational climate and self-efficacy. This research seeks to improve innovative work behavior by analyzing the contribution of self-efficacy and organizational climate to ionovative work behavior. The research was conducted on non-permanent instructors at PT PLN (Persero) Pusdiklat with samples 149. Hypothesis testing uses parametric statistical analysis and RCA (Root Cause Analysis) method. The findings of this research: (1) If self-efficacy increases, innovative work behavior will increase; (2) if the organizational climate increases, innovative work behavior will increase; (3) If selfefficacy and organizational climate increase together, innovative work behavior will increase. Based on the RCA (Root Cause Analysis) method, several priority indicators were found to improve innovative work behavior, namely: forming an innovation team, assigning internships / benchmarks, budgeting for awards, K3L training, creating Knowledge Capturing books, recruiting K3L HR, and book review.
\end{abstract}

Keywords: Innovative work behavior; Self-efficacy; Organizational climate

Abstrak: Perilaku kerja yang inovatif sangat penting untuk ditigkatkan melalui perbaikan variabel yang memengarubinya seperti iklim organisasi dan efikasi diri. Penelitian ini mencari upaya perbaikan perilaku kerja inovatif dengan menganalisis kontribusi efikasi diri dan iklim organisasi terbadap perilaku kerja ionovatif. Penelitian dilakukan pada instruktur tidak tetap di PT PLN (Persero) Pusdiklat dengan sampel 149. Pengujian bipotesis menggunakan analisis statistik parametrik dan Metode RCA (Root Cause Analysis). Temuan penelitian ini: (1) Apabila efikasi diri meningkat maka perilaku kerja inovatif meningkat; (2) apabila ikelim organisasi meningkat maka perilaku kerja inovatif meningkat; (3) Apabila efikasi diri dan iklim organisasi meningkat secara bersama-sama maka perilaku kerja inovatif meningkat. Berdasar metode RCA (Root Cause Analysis) ditemukan beberapa indicator prioritas untuk. meningkatkan perilaku kerja inovatif, yaitu: dibentuk tim inovasi, penugasan magang/benchmark, anggaran untuk, penghargaan, pelatihan K3L, buat buku Knowledge Capturing, merekrut SDM K3L, dan bedah buku.

Kata Kunci: Perilaku kerja inovatif; Efikasi diri; Iklim organisasi 


\section{INTRODUCTION}

Technological advances have a major impact on every goods and service company (Ardianti, 2006) thus forcing companies to adapt to the new atmosphere. Companies not only have to change the patterns of interaction between sellers and buyers, but technological advances also force companies to change their patterns of adapting to a more dynamic changing market environment (Ardianti, 2006). It is undeniable that both domestic and foreign companies are competing globally to make adjustments to current conditions (Simbolon, 2013). Various attempts have been made by companies to survive so that this reality becomes a challenge for the companies themselves (Maharsi, 2000). One of the efforts that companies can do is to encourage innovative behavior (Windiarsih \& Etikariena, 2018). Not only maintaining the company's existence, innovative behavior plays an important role in the growth of a company (Logahan et al., 2014).

According to Van de Ven (1986), innovation is the development and application of new ideas by individuals involved in interactions in an organization (Ven, 1986). New ideas can be in the form of a combination of previous ideas, a plan to meet current challenges, or a special approach that is perceived by the individuals involved in it (Ven, 1986). Innovative work behavior is the result of interactions between individuals as workers, between groups as a work process, and organizational processes as management practices that are commonly practiced in organizations (Soebardi, 2012).

The innovation process that occurs in an organization or company involves all individuals within the organization. In this case, individuals play an important role in developing, carrying, responding and modifying new ideas (Ven, 1986). Jones (2012). Jones (2012) stated that the innovation process is inseparable from the role of the individual's own resources, the more knowledge, skills, competence and experience the individual has, the more effective and efficient his work activities will be (Jones, 2012). In the end, innovative individuals will be more able to solve complex problems, one of which is to meet market needs. Scott and Bruce (1994) mention the term innovation at the individual level as an individual innovative behavior (Susanne G. Scott, 1994).

Innovative work behavior contributes benefits to individuals, groups, and organizations(Susanne G. Scott, 1994) so that this behavior must be developed continuously. The contribution of innovative behavior is described in more detail by Janssen (2000), including in the form of better organizational functioning as well as social-psychological benefits for employees as individuals or employees as work groups such as accuracy between perceptions of job 
demands and the resources that employees have, increasing job satisfaction and make interpersonal communication better (Onne Janssen, 2000).

Previous studies have shown several factors that lead to innovative work behavior. There are two factors, namely personal factors that come from within the individual, and factors that come from the work environment (Patterson, Fiona., Kerrin, Maire, Gatto-Roissard, 2009). Internal factors: cognitive abilities, personality, motivation, knowledge, behavior, emotions and mood; work environment factors: organizational ambidexterity, is the exploration and exploitation carried out by the company, resources that come from the social sphere (characteristics of co-workers, characteristics of leaders, feedback, social networks), job design (job characteristics, job demands, physical environment), and resources derived from the scope of the organization (organizational structure and size, organizational climate and culture, allocation of resources, incentives and rewards, and psychological contracts) (Patterson, Fiona., Kerrin, Maire, Gatto-Roissard, 2009). The novelty of this research is to describe internal (self-efficacy) and external (organizational climate) factors and the use of the RCA (Root Case Analysis) method to determine priorities for action in improving innovative behavior at PT PLN (Persero) Education and Training Center, or better known. as PLN Pusdiklat.

\section{LITERATURE REVIEW}

\section{Innovative Work Behavior}

Innovative work behavior is an individual activity that aims to introduce new and useful ideas related to processes, products or procedures (De Jong \& Den Hartog, 2010), another opinion says that innovative work behavior is all behavior individuals who are directed to produce, introduce and apply new things that are useful at various levels of the organization (Dan et al., 2018), another opinion put forward which states that innovative work behavior in workplace is a deliberate effort to find, promote, and implement ideas within the scope of tasks, work groups, and organizations to provide benefits and benefits for the organization (Akram et al., 2016)

Innovative work behavior is defined as the creation, introduction and application of new ideas or ideas in a job, group or organization to improve the role performance of the individual, group or organization (Onne Janssen, 2000). Meanwhile, Ramamoorthy et.al., (2005) argues that innovative work behavior reflects the creation of something new or different (Ramamoorthy et al., 2005). Innovative work behavior is by definition change-oriented because it involves the creation of new products, services, ideas, procedures or processes (Shanker et al., 2017). 
Innovative work behavior is the willingness of each employee to form innovations in the workplace such as improving work practices, communicating with colleagues directly, using computers, or developing new services or products (Dorenbosch et al., 2005). Then Carmeli et al., (2006) defines innovative work behavior here as a gradual process in which an individual recognizes a problem then he generates new ideas and solutions, works to promote and build support for them, and produce a prototype or model that can be applied to be used and utilized by the organization (Carmeli et al., 2006)

Based on the explanation of the concepts of the experts above, it can be synthesized that innovative work behavior is an individual activity directed at generating ideas, promoting ideas, building support and implementing ideas that are beneficial to the organization. The indicators of innovative work behavior include: 1) Idea Generation; 2) Idea Promotion; 3) Idea Championing; and 4) Idea Realization.

\section{Self-Efficacy}

According to Bandura (1997) self-efficacy is a person's belief in his ability to organize and carry out the actions needed to achieve something that is given. In social cognitive theory, low self-efficacy will have an impact on increasing anxiety and avoidance behavior (Bandura, 1997). A person will avoid activities that can worsen the situation, the cause is not because they are threatened, but because they feel they do not have the ability to manage risky aspects (Bandura, 1997). Meanwhile, Kreitner and Kinicki (2010) argue that selfefficacy is a person's belief about the likelihood of success in completing a certain task (Robert Kreitner, 2010).

Self-efficacy is a belief from within a person regarding the ability and competence to carry out tasks successfully (Hidayat, 2017). Then another opinion states that self-efficacy is a person's belief to be able to complete their task successfully (McShane \& Von Glinow, 2018). Colquitt, Lepine and Wesson (2015) define self-efficacy as a person's belief in the abilities and behaviors needed to achieve task success (Jason A. Colquitt, Jeffey A. Lepine, 2017)

Another opinion was put forward by Newstorm (2007) that self-efficacy is a belief from within a person related to his ability and competence in carrying out his duties and work (Newstrom, 2007). As for those who state that selfefficacy is an individual's perception or belief that a person can successfully complete special tasks and matters related to organizational goal commitment (Redifer et al., 2021). According to Ivancevich, J.M (2014) self-efficacy is one's belief in one's ability to do a good job in certain predetermined situations (Ivancevich et al., 2014). 
Based on the theories from the experts above, it can be synthesized that self-efficacy is the belief in a person in his ability to achieve the success of completing his task well in all situations. The indicators are as follows: 1) Selfconfidence; 2) Self-experience; 3) Self-motivation; 4) Self-defense and 5) Willingness to learn.

\section{Organizational Climate}

Organizational climate as a relatively ongoing quality of the organization's internal environment, experienced by members of the organization, affecting their behavior and can be described in terms of a set of organizational characteristics or characteristics (Madhukar \& Sharma, 2017). Another opinion states that organizational climate is a physical and non-physical work environment that affects individual perceptions of the organization, and affects the nature and behavior of the individual himself at work (Patras, 2017).

Organizational climate is defined as an individual assessment in daily life in an organizational environment and every individual in the organization experiences and understands (Çekmecelioğlu \& Günsel, 2013). Other opinions expressed Newtrom (2007) revealed that organizational climate is what concerns all existing or human environments faced in an organization where they carry out their work (Newstrom, 2007). Organizational climate is a set of tools from a work environment that is felt directly or indirectly by employees who work in this environment and think it will be a major force affecting their behavior at work (Ivancevich et al., 2014). Meanwhile, Adenike (2011) defines organizational climate as employees' perceptions of the work environment and how these perceptions can influence workers regarding attitudes and behavior (Adenike, 2011).

Organizational climate is an individual perception of an organization and a set of traits that govern individual behavior (Kundu, Kaushik, 2007). Schermerhorn (2010) argues that organizational climate is a shared perception of members about what the organization is, such as in terms of management policies and practices (John R. Schermerhorn, James G. Hunt, Richard N. Osborn, 2010).

Based on the theories from the experts above, it can be synthesized that organizational climate is the perception of the internal members of the organization towards policies and the quality of the work environment they experience, thus affecting their attitudes and behavior at work. The indicators of organizational climate include: 1) Leadership style; 2) Management support; 3) The warmth of the relationship; 4) Awards and 5) Work environment atmosphere. 


\section{METHODS}

This type of research is quantitative using a survey method with a correlational approach, this correlation technique is used to examine the relationship of three variables consisting of 1 dependent variable and 2 independent variables, the dependent variable is innovative work behavior $(\mathrm{Y})$ while the independent variable is self-efficacy $\left(\mathrm{X}_{1}\right)$ and Organizational climate $\left(\mathrm{X}_{2}\right)$, the population of this study were 235 non-permanent instructors at PT PLN (Persero) Pusdiklat, while the sample used was 149 IT'Ts. The sampling technique uses proportional random sampling, data is collected using a questionnaire instrument consisting of 1) The innovative work behavior questionnaire consists of 38 statements filled in by ITT with indicators: generating ideas, offering ideas, fighting for ideas, and realizing ideas. 2) The self-efficacy questionnaire consists of 35 statements filled out by ITT with indicators: self-confidence, self-experience, self-motivation, self-resistance and desire to learn. 3) The organizational climate questionnaire consists of 38 statement items filled out by ITT with indicators: leadership style, management support, warm relationships, appreciation and work environment atmosphere.

This research begins with the making of the instrument, then the instrument is tested for validity and reliability, after the instrument is declared valid and reliable, then the prerequisite analysis test is carried out in the form of a standard error normality test and a test of homogeneity of variance, then a hypothesis is tested using linear regression analysis, correlation analysis, analysis of the coefficient of determination, partial analysis as well as root cause analysis and corrective action using RCA (Root Cause Analysis) tools and analysis was carried out on all data obtained using SPSS 16.0.

\section{RESULTS AND DISCUSSION}

A recapitulation of the results statistical analysis data descriptions on the variables innovative work behavior, self-efficacy and organizational climate can be seen in the following table.

Table 1. Recapitulation of Statistics Description

\begin{tabular}{lccc}
\hline CRITERIA & $\begin{array}{c}\text { Innovative } \\
\text { Work Behavior }\end{array}$ & Self Efficacy & $\begin{array}{c}\text { Organizational } \\
\text { Climate }\end{array}$ \\
\hline Lots of data & 149 & 149 & 149 \\
\hline Mean & 162,56 & 151,85 & 165,05 \\
\hline Median & 165 & 155 & 168 \\
\hline
\end{tabular}




\begin{tabular}{lccc}
\hline \multicolumn{1}{c}{ CRITERIA } & $\begin{array}{c}\text { Innovative } \\
\text { Work Behavior }\end{array}$ & Self Efficacy & $\begin{array}{c}\text { Organizational } \\
\text { Climate }\end{array}$ \\
\hline Modus & 170 & 162 & 170 \\
\hline Standard deviation & 14,044 & 12,09 & 14,47 \\
\hline Varian & 197,248 & 146,172 & 209,47 \\
\hline Range & 71 & 55 & 66 \\
\hline Minimum score & 114 & 117 & 123 \\
\hline Maximum score & 185 & 172 & 189 \\
\hline Lots of classes & 8 & 8 & 8 \\
\hline Interval & 9 & 7 & 8 \\
\hline
\end{tabular}

Based on the table above, it is known that the innovative work behavior variable research data has a relatively high data distribution. The innovative work behavior variable consists of 38 valid statement items, the lowest theoretical score is 38 where this score is obtained by estimating if the respondent fills the entire questionnaire score 1 (score 1 multiplied by 38) and the highest score is 190 where this score is obtained by estimating if the respondent fills the score The total questionnaire was 5 (score of 5 multiplied by 38), the result of the calculation of the theoretical mean was $(190+38) / 2=$ 114 , while the result of the calculation empirical mean was $=162.56$. Thus, the empirical mean is greater than the theoretical mean, this indicates that the innovative work behavior variable in this study is high.

Meanwhile, the self-efficacy variable shown in table 1 above has a high data distribution, this can be seen based on the statistical description of the data where the most frequently occurring value is 162 , which is greater than the average value of 151.85. The self-efficacy variable consists of 35 valid statement items, the lowest theoretical score is 35 where this score is obtained by estimating if the respondent fills the entire questionnaire score 1 (score 1 multiplied by 35) and the highest score is 175 where this value is obtained by estimating if the respondent fills in the score. The total questionnaire was 5 (score of 5 multiplied by 35), the result of the calculation of the theoretical mean was $(175+35) / 2=105$, while the result of the calculation empirical mean was $=151.85$. Thus, the empirical mean is greater than the theoretical mean, this indicates that the innovative work behavior variable in this study is high.

Referring to table 1 above, the organizational climate variable has a data distribution that tends to be high, this can be seen based on the statistical 
description of the data where the most frequently occurring value is 170 , which is greater than the average value of 165.05. The organizational climate variable consists of 38 valid statement items, the lowest theoretical score is 38 where this score is obtained by estimating if the respondent fills the entire questionnaire score 1 (score 1 multiplied by 38) and the highest score is 190 where this value is obtained by estimating if the respondent fills in the score. All questionnaires are 5 (score of 5 multiplied by 38), the calculated theoretical mean is $(190+38) / 2$ $=114$, while the empirical mean calculation result is $=165.05$, thus the empirical mean is greater than the theoretical mean, this indicates that the climate variable organization in this study is classified as high.

\section{Testing The Analysis Requirements}

The results of the calculation of the standard error normality test for the variable estimation of innovative work behavior on self-efficacy obtained a probability value (Asymp Sig.) $=0.517>0.05$, this means that the standard error of estimation between the innovative work behavior variables on self-efficacy is normally distributed, then the calculation results of the standard error normality test, estimation of innovative work behavior variables on organizational climate obtained a probability value (Asymp Sig.) $=0.718>0.05$, this means that the standard error of estimation between innovative work behavior variables on organizational climate variables is normally distributed.

The results of the homogeneity test of the innovative work behavior variable on self-efficacy obtained a significance value $=0.069>0.05$, which means that the innovative work behavior variable on the self-efficacy variable came from a homogeneous population, while the results of the variance homogeneity test of the innovative work behavior variable on organizational climate obtained significance value $=0.959>0.05$, which means the innovative work behavior variable on the organizational climate variable comes from a homogeneous population.

\section{Hypothesis Test}

1. Hypothesis $0\left(\mathrm{H}_{0}\right)$ is rejected and hypothesis $1\left(\mathrm{H}_{1}\right)$ is accepted, meaning that there is a very significant positive relationship between self-efficacy and innovative work behavior $\left(\mathrm{r}_{\mathrm{y} 1}=0.806\right.$; $\left.\mathrm{p}<0.01\right)$, so the higher the selfefficacy, the higher the behavior innovative work, on the other hand, the lower the self-efficacy, the lower the innovative work behavior. Research by Redifer (2021) shows that self-efficacy affects creative and innovative behavior (Redifer et al., 2021), other studies show the same thing that efficacy affects innovative behavior (Dan et al., 2018), and self-efficacy fosters entrepreneurship and innovation (Newman et al., 2018) . 
2. Hypothesis $0\left(\mathrm{H}_{0}\right)$ is rejected and hypothesis $1\left(\mathrm{H}_{1}\right)$ is accepted, meaning that there is a very significant positive relationship between the organizational climate variables on innovative work behavior $\left(\mathrm{r}_{\mathrm{y} 2}=0.705 ; \mathrm{p}<0.01\right)$, so the higher the organizational climate, the higher the innovative work behavior, on the contrary if the lower the organizational climate, the lower the innovative work behavior. Research by Kang et al., (2016) found that organizational climate affects innovative work behavior (Kang et al., 2016), climate affects team innovativeness (Açikgöz \& Günsel, 2011) and climate affects the innovativeness of a company (Çekmecelioğlu \& Günsel, 2013).

3. Hypothesis $0\left(\mathrm{H}_{0}\right)$ is rejected and hypothesis $1\left(\mathrm{H}_{1}\right)$ is accepted, meaning that there is a very significant positive relationship between the self-efficacy variable and the organizational climate variable together on the innovative work behavior variable $\left(\mathrm{r}_{\mathrm{y} 12}=0.836 ; \mathrm{p}<0.01\right)$, so that the higher the selfefficacy variable and the organizational climate variable together, the higher the innovative work behavior variable, on the contrary if the lower the selfefficacy variable and the organizational climate variable together, the lower the innovative work behavior variable.

\section{Root Cause Analysis And Corrective Action}

The method of analyzing suggestions or recommendations for research results from this thesis uses root cause analysis (RCA), according to Rooney and Heuvel (2004) which is defined as a logical structure that defines what events lead to an unwanted /expected event (Rooney \& Vanden Hauvel, 2004). According to Andersen and Fagerhaug (2006), the general stages when carrying out a root cause analysis include (Andersen Bjørn, 2006):

1. Defining the problem

In 2019, the total number of ITT PLN Pusdiklat numbered 235 people, who took the initiative to make innovative works of 49 people or $20.85 \%$ of the total ITT, so there was still a gap of 186 people or $79.15 \%$ of ITTs who did not make innovative works.

\section{Form a team}

In finding the root cause of an effective problem, namely through team building, this will be effective if it involves people who are very familiar with the details of the problem and it is very important to involve people who are experienced in the process where the problem occurs, so that when brainstorming will have a variety of views, knowledge, experiences and different approaches to the issues raised. 
3. Collecting problem data

Based on the research data, it can be seen that the average score of indicators obtained in both the independent and dependent variables, where the lowest average score of the innovative work behavior variable is to generate ideas of 3.70; Furthermore, the lowest average indicator score on the self-efficacy variable is self-motivation of 3.59 and the last average score of the lowest indicator on the organizational climate variable is the work environment atmosphere of 3.79 .

4. Identifying the root of the problem

In this study, the tools used to help identify the root of the problem are using the " 5 whys" method or called why why analysis, the 5 whys method is a method that functions to explore the root causes of problems and their relationship to problems that arise (Serrat, 2017), the identifying the root of the problem result as seen in Figure 1.

5. Identifying corrective actions

After getting the root causes of problematic indicators, the next step is to identify corrective actions to address the root of the problem as seen in Figure 1, namely book review obligations, internship / benchmark assignments, an innovation team is formed, create a Knowledge Capturing book, plan a budget awards, plan HSSE training, plan to recruit HSSE HR.

6. Set priorities for action

After obtaining several alternative corrective actions, the next step is to prioritize action using the APM (action priority matrix) tools for corrective actions that have been identified through an assessment based on FGD (Focus Group Discussion), the action priority matrix is a decision-making technique by making a simple diagram that helps in choosing which activities should be prioritized and which should be canceled (Manktelow, 2007). 
Table 2. The Results Of The Priority Matrix Assessment Through FGD

\begin{tabular}{|c|c|c|c|c|c|c|c|c|c|c|c|c|c|}
\hline \multirow{2}{*}{ NO } & \multirow{2}{*}{$\begin{array}{l}\text { CORRECTIVE } \\
\text { ACTION }\end{array}$} & \multicolumn{5}{|c|}{ PARTICIPANTS FGD } & \multirow{2}{*}{$\begin{array}{c}\text { AVERAGE } \\
\text { EFFORT }\end{array}$} & \multicolumn{5}{|c|}{ PARTICIPANTS FGD } & \multirow{2}{*}{$\begin{array}{r}\text { AVERAGE } \\
\text { IMPACT }\end{array}$} \\
\hline & & $\mathbf{A}$ & B & $\mathrm{C}$ & $\mathrm{D}$ & $\mathbf{E}$ & & $\mathbf{A}$ & B & $\mathrm{C}$ & $\mathbf{D}$ & $\mathbf{E}$ & \\
\hline 1 & $\begin{array}{l}\text { Book review } \\
\text { obligation }\end{array}$ & 4 & 4 & 4 & 4 & 4 & 4,0 & 2 & 3 & 1 & 3 & 3 & 2,4 \\
\hline 2 & $\begin{array}{l}\text { Internship / } \\
\text { benchmark } \\
\text { assignments }\end{array}$ & 0 & 1 & 1 & 1 & 1 & 0,8 & 3 & 4 & 4 & 4 & 4 & 3,8 \\
\hline 3 & $\begin{array}{l}\text { Created an } \\
\text { innovation team }\end{array}$ & 1 & 1 & 0 & 1 & 0 & 0,6 & 4 & 4 & 4 & 4 & 4 & 4 \\
\hline 4 & $\begin{array}{l}\text { Create a } \\
\text { Knowledge } \\
\text { Capturing book }\end{array}$ & 2 & 3 & 3 & 3 & 3 & 2,8 & 2 & 2 & 2 & 3 & 3 & 2,4 \\
\hline 5 & $\begin{array}{l}\text { Plan an award } \\
\text { budget }\end{array}$ & 1 & 2 & 1 & 1 & 0 & 1 & 4 & 4 & 4 & 4 & 4 & 4 \\
\hline 6 & $\begin{array}{l}\text { Plan HSSE } \\
\text { training }\end{array}$ & 1 & 1 & 2 & 1 & 1 & 1,2 & 3 & 4 & 3 & 3 & 2 & 3 \\
\hline 7 & $\begin{array}{l}\text { Plan HSE HR } \\
\text { recruitment }\end{array}$ & 4 & 4 & 3 & 4 & 3 & 3,6 & 4 & 3 & 3 & 3 & 2 & 3 \\
\hline
\end{tabular}

Based on the table results of the priority matrix assessment through FGD are obtained as shown below.

Information:

Effort

$0=$ Very Easy

$1=$ Easy

$2=$ Moderate

$3=$ Difficult

$4=$ Verry Difficult $4=$ Very Impactful

$2=$ Moderate

$3=$ Impact

$0=$ No impact

$1=$ Less Impact

te

Root

cause 


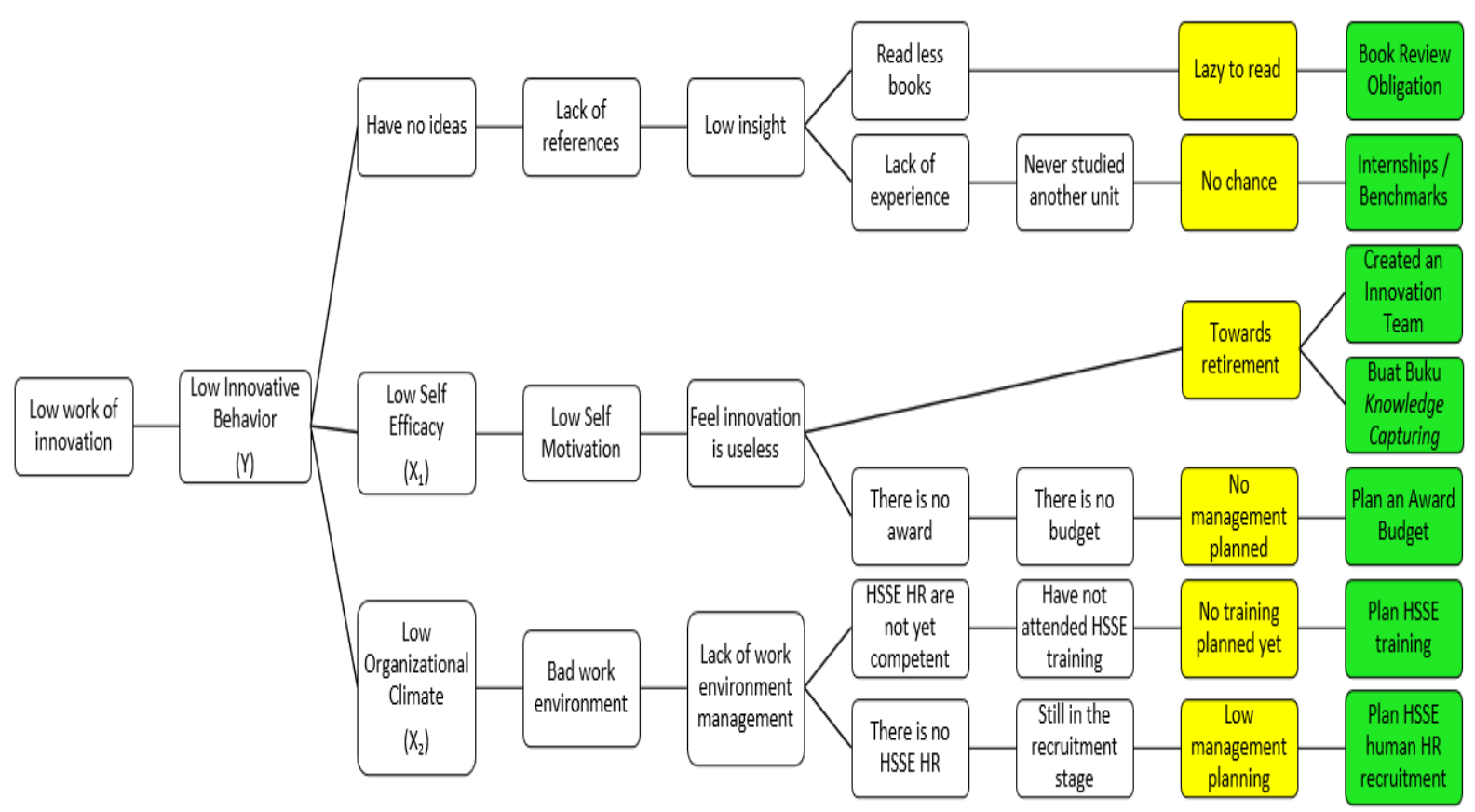

Following are the results of root cause identification and corrective action

\section{Figure 1. Results of Root Cause Identification and Corrective Action}

From the table above, it can be seen that the priority actions that must be chosen are in the Quick Wins quadrant, namely priority actions that must be completed because they have a large impact with little effort, including:

1) No. $3=$ Created an innovation team

2) No. 2 = Internship / benchmark assignments

3) No. $5=$ Plan an award budget

4) No. $6=$ Plan HSSE training

Then other corrective actions are in the Major Project quadrant where this action can have a relatively high impact, but requires a large amount of effort so that it can take a relatively long time, if you still want to complete actions in this quadrant make sure it can be completed quickly and efficiently, actions on Major The projects include:

1) No. $4=$ Create a Knowledge Capturing book

2) No. $7=$ Plan HSSE HR recruitment

3) No. $1=$ Book review obligation 


\section{CONCLUSION}

Based on the results of the study, it is concluded that 1) the increasing self-efficacy will also increase IT'T's innovative work behavior with a correlation value of $\left.\mathrm{r}_{\mathrm{y} 1}=0.806(\mathrm{p}<0.01) ; 2\right)$ With the increase in organizational climate, the innovative work behavior of IT'T will also increase with a correlation value of $\mathrm{r}_{\mathrm{y} 2}$ $=0.705(\mathrm{p}<0.01) ; 3)$ By increasing self-efficacy and organizational climate together, it will also increase IT'T innovative work behavior with a correlation value of $r_{\mathrm{y} 12}=0.836(\mathrm{p}<0.01)$. 4) For priority actions that must be taken in an effort to improve IT'T innovative work behavior, including: forming an innovation team, assigning internships/benchmarks, planning an award budget, planning HSSE training, creating Knowledge Capturing books, planning to recruit HSSE HR, and book review obligations.

Referring to the results of the root cause analysis and corrective actions in the Quick Wins quadrant, it can be used as an alternative input for PT PLN (Persero) Pusdiklat, including, First: Improved Indicators to Produce Ideas. The low level of ITT in generating ideas is due to a) laziness in reading so that the insights they have are low so that it is difficult to generate new breakthrough ideas, then the recommended action to improve it is the obligation to review books, given this task IT'T is encouraged to carry out self-development through reading books, b ) there is no opportunity to study other units so that the experience they have is low in looking for new ideas to improve the quality of the learning process, so the recommended action is to be given an internship / benchmark assignment, it is hoped that with the opportunity to see the excellence of other units it will add ITT insights in finding ideas new useful so that it can be applied. Second: Increased Self-Motivation Indicators. The low self-motivation of ITT is caused by a) entering the retirement period so that they feel it is not useful to innovate, then the recommended action is to form an innovation team so that ITT who will retire is encouraged and enthusiastic to create innovative work, b) the management does not plan an award budget related to work reward innovation, it causes ITT to feel there is no benefit in making innovative work, so it is necessary to plan an award budget. Third: Improvement of Work Environment Indicators. The work environment is not conducive because a) HSSE human resources are not yet competent, so planning is needed regarding HSSE training for these human resources, because if the HSSE HR who manages the work environment is competent, it will improve the quality of the work environment, b) the absence of HSSE HR who are responsible for the management of the work environment, so it is necessary to plan to recruit competent HSSE HR, because with the presence of HSSE HR who manages it will improve the quality of the work environment. 


\section{REFERENCES}

Açikgöz, A., \& Günsel, A. (2011). The effects of organizational climate on team innovativeness. Procedia - Social and Behavioral Sciences, 24, 920-927. https://doi.org/10.1016/j.sbspro.2011.09.102

Adenike, A. (2011). Organizational Climate As a Predictor of Employee Job Satisfaction : Evidence From. Business Intelligence Journal, 4(1), 151-165.

Akram, T., Lei, S., \& Haider, M. J. (2016). The impact of relational leadership on employee innovative work behavior in IT industry of China. Arab Economic and Business Journal, 11(2), 153-161. https://doi.org/10.1016/j.aebj.2016.06.001

Andersen Bjørn, T. F. (2006). Root Cause Analysis Simplified Tools and Techniques. ASQ Quality Press.

Ardianti, R. (2006). Tinjauan Terhadap Dampak Teknologi Informasi Dalam Organisasi Bisnis Dan Upaya Untuk Merealisasikan Manfaat Positifnya. Jurnal Manajemen Dan Kewirausabaan, 8(2), 72-77. https://doi.org/10.9744/jmk.8.2.pp.72-77

Bandura, A. (1997). Self-Efficacy: The Exercise of Control. W. H. Freeman \& Co. https://doi.org/10.1891/0889-8391.13.2.158

Carmeli, A., Meitar, R., \& Weisberg, J. (2006). Self-leadership skills and innovative behavior at work. International Journal of Manpower, 27(1), 7590. https://doi.org/10.1108/01437720610652853

Çekmecelioğlu, H. G., \& Günsel, A. (2013). The Effects of Individual Creativity and Organizational Climate on Firm Innovativeness. Procedia - Social and Behavioral Sciences, 99, 257-264. https://doi.org/10.1016/j.sbspro.2013.10.493

Dan, X., Xu, S., Liu, J., Hou, R., Liu, Y., \& Ma, H. (2018). Innovative behaviour and career success: Mediating roles of self-efficacy and colleague solidarity of nurses. International Journal of Nursing Sciences, 5(3), 275-280. https://doi.org/10.1016/j.ijnss.2018.07.003

De Jong, J., \& Den Hartog, D. (2010). Measuring innovative work behaviour. Creativity and Innovation Management, 19(1), 23-36. https://doi.org/10.1111/j.1467-8691.2010.00547.x

Dorenbosch, L., Engen, M. L. va., \& Verhagen, M. (2005). On-the-job innovation: The impact of job design and human resource management through production ownership. Creativity and Innovation Management, 14(2), 129-141. https://doi.org/10.1111/j.1476-8691.2005.00333.x

Hidayat, R. (2017). Peningkatan Aktivitas Komunikasi Interpersonal Dalam Organisasi Melalui Perbaikan Efikasi Diri, Kepemimpinan Dan Kekohesifan Tim. Kelola: Jurnal Manajemen Pendidikan, 4(2), 161. https://doi.org/10.24246/j.jk.2017.v4.i2.p161-170 
Ivancevich, J. M., Konopaske, R., \& Matteson, M. T. (2014). Organizational, Behavior \& Management, Tenth Edition. In McGraw-Hill Companies.

Jason A. Colquitt, Jeffey A. Lepine, M. J. W. (2017). Organizational Behavior: Improving performance and outcomes (Vol. 4, Issue 4). McGraw- Hill Education. https://doi.org/10.1002/pdh.22

John R. Schermerhorn, James G. Hunt, Richard N. Osborn, M. U.-B. (2010). Organizational Behavior. John Wiley \& Sons, Inc.

Jones, B. (2012). Innovation and Human Resources: Migration Policies and Employment Protection Policies, Compendium of Evidence on the Effectiveness of Innovation Policy. MIoIR-NESTA: Manchester/London. Compendium of Evidence on the Effectiveness of Innovation Policy Intervention Project, April. https://doi.org/10.13140/RG.2.2.25686.04168

Kang, J. H., Matusik, J. G., Kim, T. Y., \& Phillips, J. M. (2016). Interactive effects of multiple organizational climates on employee innovative behavior in entrepreneurial firms: A cross-level investigation. Journal of Business Venturing, 31(6), 628-642. https://doi.org/10.1016/j.jbusvent.2016.08.002

Logahan, J. M., Indrajaya, A., \& Proborini, A. W. (2014). Analisis Pengaruh Perilaku Inovatif dan Self - Esteem terhadap Organizational Citizenship Behavior di PT. Stannia Binekajasa. Binus Business Review, 5(1), 396. https://doi.org/10.21512/bbr.v5i1.1261

Madhukar, V., \& Sharma, S. (2017). Organisational Climate: A Conceptual Perspective. International Journal of Management, IT and Engineering, 7(8), 276-293.

Maharsi, S. (2000). Pengaruh Perkembangan Teknologi Informasi Terhadap Bidang Akuntansi Manajemen. Jurnal Akuntansi Dan Keuangan, 2(2), 127 137. https://doi.org/10.9744/jak.2.2.pp.127-137

Manktelow, J. (2007). Mind Tools: Essential Skills for an Excellent Career. Mind Tools 2007.

McShane, S. L., \& Von Glinow, M. A. Y. (2018). Organizational Behavior: Emerging Knowledge. Global Reality (8th) Edition. In McGraw-Hill.

Newman, A., Tse, H. H. M., Schwarz, G., \& Nielsen, I. (2018). The effects of employees' creative self-efficacy on innovative behavior: The role of entrepreneurial leadership. Journal of Business Research, 89(March), 1-9. https://doi.org/10.1016/j.jbusres.2018.04.001

Newstrom, J. W. (2007). Organizational behavior: Human behavior at work. McGrawHill Irwin.

Onne Janssen. (2000). Job demands, perceptions of effort-reward fairness nd innovative work behavior. Journal of Occupational and Organizational Psychology, 287-302. 
Patras, Y. E. (2017). Hubungan Kepuasan Kerja Dan Iklim Organisasi Dengan Komitmen Organisasional Guru. Pedagogia, 9(1), 454.

Patterson, Fiona., Kerrin, Maire, Gatto-Roissard, G. (2009). Characteristics \& Behaviours of Innovative People in Organisations: Literature review A paper prepared for NESTA Policy and Research Unit (NPRU). May, 1-63.

Ramamoorthy, N., Flood, P. C., Slattery, T., \& Sardessai, R. (2005). Determinants of Innovative Work Behaviour: Development and Test of an Integrated Model. Creativity and Innovation Management, 14(2), 142-150. https://doi.org/10.1111/j.1467-8691.2005.00334.x

Redifer, J. L., Bae, C. L., \& Zhao, Q. (2021). Self-efficacy and performance feedback: Impacts on cognitive load during creative thinking. Learning and Instruction, 71(August 2020), 101395. https://doi.org/10.1016/j.learninstruc.2020.101395

Robert Kreitner, A. K. (2010). Organizational Behavior. McGraw- Hill Irwin. https://doi.org/10.5005/jp/books/12694_46

Rooney, J. J., \& Vanden Hauvel, L. N. (2004). Root cause analysis for beginners. Quality Progress, 37(7), 45-53.

Serrat, O. (2017). The Five Whys Technique. Knowledge Solutions: Tools, Methods, and Approaches to Drive Organizational Performance, 1-1140. https://doi.org/10.1007/978-981-10-0983-9

Shanker, R., Bhanugopan, R., van der Heijden, B. I. J. M., \& Farrell, M. (2017). Organizational climate for innovation and organizational performance: The mediating effect of innovative work behavior. Journal of Vocational Behavior, 100, 67-77. https://doi.org/10.1016/j.jvb.2017.02.004

Simbolon, F. (2013). Strategi Pemasaran Global di Pasar Indonesia. Binus Business Review, 4(1), 405-413. https://doi.org/10.21512/bbr.v4i1.1406

Soebardi, R. (2012). Perilaku Inovatif. Jurnal Psikologi Ulayat, 1(1), 57-74. https://doi.org/10.24854/jpu12012-10

Susanne G. Scott, R. A. B. (1994). Determinants of Innovative Behavior: A Path Model Of Individual Innovation In The Workplace. Acodemy of Management Journal, 37(3), 580-607.

Ven, A. H. (1986). Central problems in the management of innovation. Management Science, 32(5), 590-607. https://doi.org/10.2307/2631848

Windiarsih, R., \& Etikariena, A. (2018). Hubungan Antara Kepribadian Proaktif dan Perilaku Kerja Inovatif di BUMN X. Journal Psikogenesis, 5(2), 123. https://doi.org/10.24854/jps.v5i2.501 